\title{
Islam Agaid and Its Place in the Religious and Philosophic Sciences
}

\author{
Ebilova Zekiyye Aqababa \\ National Akademy of Sciences of Azerbaijan, International Relations Department of Institute of Manuscripts named after Muhammad \\ Fuzuli
}

\begin{abstract}
Belief has served as an integral part of human life and society since ancient times. Its essence and reasons are explained in different ways. Reflecting upon his issue the ancient philosophers had also put forward the various assumptions. As is evident, agaid and belief are major focus of interest in every religion as a principal question. A basis of the disagreement and differences between the different religions and agaid is connected to the issues of belief. The issue of belief and its principles are studied not only in theology, but also in the sciences like philosophy, sociology and psychology. As religion and agaid is a phenomena specific for human nature, his spiritual world and essence. When it comes to Islam the issue of belief has drawn attention as a key topic, probably the most key topic with which the various groups have treated from its initial stages. This topic has kept its urgency over the course of Islamic history. There are hundreds of addressed and unaddressed manuscripts in Turkish, Arabic and Persian on the Islam belief in the treasure of The Institute of Manuscripts named after Muhammad Fuzuli of the National Academy of Sciences of Azerbaijan. There are the valuable works among them on the agaid of Islam as well as about belief of the different agaid.
\end{abstract}

Key words: Islam, Figh law, belief, Kalam, Tasawwuf, agaid.

\section{Introduction}

Agaid science places between scientifically-philosophical sciences. The idea that God is sole creative and guiding force I mean Eastern pantheism takes a major place in this science. There are many manuscripts connected with this theme in The Institute of Manuscripts named after Muhammed Fuzuli. I mentioned the works that some scholars applied and wrote on this subject. There are also Azerbaijanians between them.

\section{Materials and Methods}

I searched Azerbaijani, Arabic and Russian works of some authors. Manuscripts connected to the theme of "Islam agaid and its place in the religious and philosophic sciences" take a major place between them.

Belief has served as an integral part of human life and society since ancient times. The description of

Corresponding author: Ebilova Zekiyye Aqababa, Ph.D., research fields: The history of religion and its philosophy. belief and agaid is presented with a variety of approaches and under different points of view among the religious and mythological, religious and philosophical teachings taken place in the religious and philosophical worldview of the Azerbaijani people. Therefore, its essence and reasons are explained in different ways, even contradictory to each other. Reflecting upon this issue the ancient philosophers had also put forward the various assumptions. For Socrates human being should not meddle in the matters belonging to the nature. The God has dominion over it and it is no concern of a human being to learn the laws of nature. The main task of a human being is to know himself [1]. For Plato a purpose for all living things is a happiness consisting of having a blessing. Spirit strives for wisdom about blessing trying to gain the blessings. In the attitude of Plato the God is not only a living being. $\mathrm{He}$ is a goodness of the blessings. The God is a blessing Himself. The God is graceful and He loves grace. Therefore, He creates a world in conformity 
with Himself, because He may be happy just in a case when life endowed by Him to the world is happy. He connected the ideas with matter and created space [1]. For Aristotle the God is the Supreme principle, idea for blessing. He is eternal and only one. The God is the initial motive and final reality. The God is an embodiment of goodness and intellect. A man wishing to be like Him should increase intellect [1]. In the Ishraqiyah philosophy the material world is considered a world of darkness and shades. The followers of Ishraqiyah who took as a basis only illumination and named essentially not-being of the shades which comprised the material world, as a matter of fact came nearer to Platonism. Passing the illumination succession, human soul reaches the abstract illumination world. Like Sufis the followers of Ishraqiyah distinguish the sensual, intellectual and intuitive stages in cognition. They propagated to be isolated from this world for cognizing absolute truth and expressly stayed in the idealism front [2].

As is evident, agaid and belief are a major focus of interest in every religion as a principal question. A basis of the disagreement and differences between the different religions and agaid is connected to the issues of belief. The issue of belief and its principles are studied not only in theology, but also in the sciences like philosophy, sociology and psychology. As religion and agaid is a phenomena specific for human nature, his spiritual world and essence, it is more difficult and complicated to conduct research towards it.

When it comes to Islam the issue of belief has drawn attention as a key topic, probably the most key topic with which the various groups have treated from its initial stages. This topic has kept its urgency over the course of Islamic history and is not put aside from the range of interest of the different scientific circles in our times too.

In the medieval period when the sciences were divided into two groups as religious and secular, the first ones were named declarative, and the second ones were named intellectual. Abu Nasr Al-Farabi At-Turki (870-950) who gave "classification of sciences" for the first time ever, divided the sciences into five sections and named the fourth section "natural (physical) science and its sections and theological (metaphysical) science and its sections". The section consists of three parts. The third part treats with the non-material creatures. Farabi writes that though there are many such creatures, these creatures rising to more perfect "are completed finally with the Perfect one who has not the contrary, analogue, nothing but $\mathrm{Him}$ at the degree of his existence, with the Initial who has not any initial before Him with the Ancient who has not anything before Him, with the existence whose existence does not depend on anything else" [3]. $\mathrm{He}$ is the one, ancient God. He gave inimitability as $\mathrm{He}$ is one, single. Only He is worthy of belief. This section also treats with the Metaphysics, the impartial, fair, regulated impact of the God on the creatures.

When it comes to Metaphysics, literally meaning "coming after physics", Aristotle named it "the first philosophy, and accepted as the bases were not reachable for the highest organs of sense of all creature and cognized just theoretically and unchangeable, and obligatory for all sciences" [2]. The East peripatetic school divides philosophy into two parts as theoretical and practical ones. The first part treating with states of being of things includes metaphysics, physics and mathematics, and the second section considering the activity of men includes ethics, living actions, management of city, nation and state. In the opinion of Ibn Sina (980-1037), metaphysics is a science "for the beginning of the tings in creature, for initial reason". The greatest representative of the East peripatetic school is an Arabian philosopher Yagub Kindi (800-873) belonging to the Mutalism trend. He has the great efforts in establishing of the philosophic terms in Arabic. The philosopher-follower of Mutalism considering the God both creator and beginning of the world acted 
mainly from a position of Aristotelianism in statement and solution of the philosophic problems [4]. For Kindi, an eternal is that whose absence is not possible, so he never die. Because, being of the Eternal is not from the others. He is a substance, but not attribute. Therefore, there is not a reason for his creation. As there is not sex, type, form for the eternal, initial, he cannot be visible. Each Muslim accepting all of these, believe in one God.

It should be noted that all areas and components of the Islam culture have been established in connection with belief ruling in the social and cultural environment of spreading of this religion. Therefore, the right conscious of those areas and components depend on the right explanation and conscious of the essence of the matter.

The science learning the issues of belief have been named differently in the various periods. In those periods this science was named Figh. As that time the sciences connected with belief and behavior were not divided from each other, they were composed in the same books. They all together were named Figh [5].

By the time the separate booklets had been written on the principles of agaid and so the figh and byword, that is agaid had begun to be separated. This mentioned form of the primary Figh shows itself in the work of "Al-Fighul-Akbar" of Abu Hanifa (v.150/767). Though this booklet named Figh, it treated with the agaid principles of Islam. And it was named "Al-Fighul-Akbar" just for agaid was in foreground of it. And from it, a science which topic was the belief principles began to be named "Al-Fighul-Akbar" [6].

This science treats with the claims of belief of the Islam religion. Belief previously was recognized as a science treated with the principles of agaid of the Islam science briefly, without arguments, by Salaf way. There are the similarities and differences of these two sciences. Belief is interpreted as a science treating with Vajibal-Vucud, that is origin, definitions and actions of the God, but the Byword a science treating both with them and the states and specifications of possibility.

Elman Jalilov accepting the Byword as one of the theological sciences notes it to be named also with the name of "Usuli-din": "Its topic is a form and essence of being of the God, creation of spirit and its passing to creatures, in other words its recognition, state and qualities. As the Byword studies the God from the viewpoint of Islam religion, theological requirements, as a matter of fact it studies the principles of religion. Therefore, all religion theories are established on it" [7]. Elman Jalilov considers a difference of the Byword science from other theological sciences in its presenting the general religious thought on the Islam religion, the God and His definitions.

Another difference between the Byword and Belief sciences is that Byword is based on the intellectual and declarative evidences. But such disputes are not given in the Belief science. Here the principles of agaid expressed in the Koran verses and hadiths are sought as they are and wanted like this [8]. At the same time, the belief and byword sciences are the sides completing each other.

It should be noted that all areas and components of the Islam culture have been established in connection with belief ruling in the social and cultural environment of spreading of this religion. Therefore, the right conscious of those areas and components depends on the right explanation and conscious of the essence of the matter.

Each civilization has a common dynamic thinking system and this system has its specific structure and constituents. Islam thinking system has four main wings: Salafiyya, Kalam, Tasawwuf and philosophy. Suleiman Uldagh based on that philosophy is included more to the non-Islam sciences, states three parties of the Islamic thought movement:

(1) Salafiyya giving priority to declaration, evidence and story; 
(2) Kalam giving importance to reason, argument and opinion;

(3) Tasawwuf giving more significance to discovery and inspiration [9].

The main science field where the issues connected to belief are solved is included in the main classification system of sciences to the circle of interest of Belief and Byword.

The twofold division draws attention in the classification of science:

(1) Arabic scientists, traditional sciences or religious sciences;

(2) Non-Arabic and non-traditional sciences.

It should be noted that the issue of belief takes place within the religious sciences and in this list the first place is taken by the Koran sciences and interpretation, and the second place by the Hadith and Sunnah. And the topic of belief is analyzed in Salaf, Kalam and Tasawwuf. Imam Galazi gives an important place to the religious sciences in the classification of sciences and studies the issue of agaid in the separate section [10]. And Jalaladdin Suyuti (d. 911 (H)) gives a special place to the principles of religion in his classification.

In general the belief taking a special place in the Islamic theology formed since the VIII century, and then passed a way of progress by development if the Kalam and Figh sciences. In that period the booklet in the meaning of "isbatul-vajib", "asmayu-husna", "isbatu anbiya", "imamat", "gadar" and etc., were risen, and the comments and notes were wrote to those booklets. Besides its previous polemic (arguable) character, the belief expressed the position of each author and school by the laconic and accurate expressions. In its initial form the source the belief based were the Koran and Hadithes. The first works in this topic belong to the Syrian theologians, among them we can note Umayya bin Osman, Ahmad bin Khalid bin Muslim and Mohammad bin Abdullah, and etc.

In the IX-XI centuries when the Byword schools formed in Islam, the Belief science also stepped to the new stage. In the terms of Abbasids, the Muslims got acquainted with the scientific and philosophic works translated from Hindi, Greece, Pahlavi and Syrian languages in a result of the intensive translation activities. As this activity started in "Darul-Hikmat" established in the term of Caliph Mansur, it reached the productive stage in the term of Mamun. The Muslim gotten acquainted with the scientific and philosophic thoughts of other nations, conducted the researches in the Byword science with a new approach. It was created two main schools-the Motazila and Ashari movement competed with each other [11]. Though the oppositional scholastics-followers of Motazila movement tried to prove the oneness of God by the logical evidences, they refused the eternity of the attributes of the God, as well as stated that the Koran was established afterwards. The followers of Motazila movement were solidary that the God is One. Nothing is similar to Him. He is listening and seeing, but He is not body, nor illusion, not figure, nor image, not meat, nor blood, not person, nor substance. Some of the followers of Khariji, as well as Muji and Shiah share the thoughts of Motazila on the oneness of God. Some of the followers of Motazila movement are solidary that the Creator is everywhere, He rules everything, His ruling is everywhere. As a result of the course of the ideological fight in Azerbaijan, the Motazila movement declared heresy from the ending of the IX century by the ruling circles gradually gave its place to the orthodox Islamic scholastics-Ashari movement. Though the Ashari movement founded by Abulhassan Ashari (879-935) accepted the eternity of the descriptions of the God, they did not refer to the God a human image as the Sifati movement. The God is knowing, mighty, alive [11].

At the same time, there was discovered the changed and novelty in forming of the Islam law. Five schools had gradually formed. In that period the followers of Motazila movement had written the significant works in the field of belief and among them we can show "Mafhumu-adl fi tafsiril-Mutazila" by Mohammad 
Kamil Ahmad, "Al-Metafizika indal-Mutazila" by Mohammad Sabri Osman, "Falsafatil-gadar fi fikri Mutazila" by Samih Dughayman, "Mushkilatil-hurriyyatil-insaniyya" by Mohammad Umara al-Mutazila, “Al-Masarul-fikri beyn'l-Mutazila vash-shiah" by rasul Jafaryan and others [11].

The traditional Byword followers prepared a number of works in the IX century. A little later it was written "Agaid" by Ashari and "Agaid" by al-Juveyni. And the important books concerning the classic belief were written by the authors like Ibn Batta, Gazali, Shahristani, Abdulgadir al-Gilanii (Jilani), Najmaddin an-Nasfi. The belief literature takes a great place among the texts treating with the Islam sciences created after death of the Prophet. Beginning from the first periods the works named "Kitabut-tovhid", "Agida", "Usuli-din", "Kitabus-sunna", "Fighul-akbar", "Khilafat va imamat" and others were brought up. The books written on the history of agaid before the belief can also be considered the Belief works.

There is the section related with the belief in the most of the hadith books. "Kitaabus-sitta", "Al-muvatta", "Sahihul-bukhari mukhtasaru tajridis-sahih", "Usulu-kafi” and etc., are among them.

And one of the Islam sciences studying the issue of belief is Tasawwuf. The topics related to belief in the Tasawwuf books mostly analyzed from the viewpoint faith-belief of its author. There are the thought of belief in the works of "Ahyayu-ulumid-din" by Imam Gazali, "Fususul-hukam" by Ibnul-Arabi, "Maktubat" by Imam Rabbani.

The works of "Al-Agaid" by Abil-Leys Samagandi, "Agaid" by Abul-Barakat an-Nasafi, "Tajrid" by Khaja Nasiraddin Tusi, "Al-agaidul-Adudiyya" by Iji, "al-Agaid" by Sunusu, "Agaidul-islam" by Ardabili, "Vasiyya" by Birgavi written a bit later and going round the world in a form manuscript were prepared from the viewpoint of belief.

There are hundreds of addressed and unaddressed manuscripts in Turkish, Arabic and Persian on the
Islam belief in the treasure of the Institute of Manuscripts named after M. Fuzuli of the National Academy of Sciences of Azerbaijan. There are the valuable works among them on the fatihs of Islam, as well as about belief of the different agaid.

It is written in the manuscript under code of B-2397 named "Burhanut-tovhid" that: "The most virtue among the sciences is them which study the religion and Sharia of the God. The agaid and Islam are protected by the science of belief. It is basis of the Sharia sciences. Head of the religious knowledge. Remedy for the eternal happiness is gained by it" [12].

The manuscript collection coded under B-733 includes the work of the well-known Hanafi Figh, Byword and interpretation scientist Najmaddin Abu Nafs Omar bin Ahmad bin Ismail an-Nasafi (1068-1142) "Agaid". The text began from praising of being of the God, the Koran and Prophet, and devoted to brief interpretation of the Muslim belief. This little booklet has become an object of interest of the Muslim world, and there has been written many comments and notes about the work [13]. The manuscripts of it are in many libraries of the world. There is one more copy of the text coded under B-7313, more than ten comments and one note about the text in the Institute of Manuscripts named after M. Fuzuli of the National Academy of Sciences of Azerbaijan. They are the followings: B-4833 (366); A-1029 (373); B-2124 (381); B-1431 (374); B-5903 (371); D-263 (370); B-3813 (375); B-3656 (376); B-2063 (382); B-6844 (379); B-503 (378); B-613 (383); B-134 (388); B-2203 (367).

Note: B-2610 (344).

In addition to the listed ones, it is protected in the treasure of the institute the Arabi language addressed manuscripts like "Agaidul-khamsin" (M-64 (384) B-643 (385); "Sharhul-agaidil-adudiyya" (B-3156 (352); $\quad$ B-601 (361); $\quad$ B-3197 (365)), "Shahul-agaidil-Jalaliyya" (B-435 (364); B-755 (363); A-1189 (62)), "Agaidul-firgatin-Najiyyati” (B-4157) (388), “Agaid” (B-6817), “Agaidush-shia va 
ahlis-sunnal-jamaa" (B-5711) (357), "Sharhu risalati-isbatil-vajib" (B-5741) (327), "Sharhu agaid" (B-4785) (347), "Elmul-hal" (B-6835) (241), "Isbatul-vajib ad-Davvani" (B-322) (358).

One of the most important of the Arabic language manuscripts is the above mentioned work "Tajrid" by Khaja Nasiradin Tusi. Allama Muhaggig Nasiraddin Abu Jafar Mohammad bin Tusi wrote on how he wrote the work: "I answered the questions on the preparation of the issues of belief. I prepared as an order unique individuals with the rare pearls of treasure of belief. It was roared the matters of efforts ruling me and enhancing my belief. I named it "Tajridul-agaid" [14].

Akhund Haji Abdulkarim agha Badkubi (1867-1961) has given a great place in interpretation of the issues of belief in his activities, as well as in his work of "Irshadul-mutahayyirin" made citations from "Tajrid" by Khaja Nasiradin Tusi and from the note of Ardabili to that work.

There was prepared the textbooks for the pupils studying in the mosques and madrasahs under the influence of the mentioned works. The work of the Azerbaijani author Hassan bey Malikzadeh Zardabi "Soil, flame, water and air" treats with creation of the universe and a role of the known four elements in this creation. Talking on the miracles of the Prophet in the work of "Tarikhu-mugaddas ila tarikhi islam" Akhund Abdurrahim Hadizadeh Bakili in particular stayed on His meraj, talked on his unlikely meraj towards the God passing the heavens.

Over the course of Islamic history it has been written the books of belief in verse for learning easily and for a long time within education and training. These works in Arabic, Persian and Turkish have been written in Aruz metre. The manuscript coded B-1719 is named "Nuzumul-aali" and from Ishag bin Hassan Rizai At-Togati (d.1688). There are also the copies coded B-3172 and B-2985 of the work known by the name of "Manzumatu-agaid" and consisting of 376 couplets.
The topic of belief reflected in the Soviet, in particular in the Azerbaijani Islamic studies.

\section{Conclusions}

The theme of these works which are product of the various historical periods is same. And this testifies that as a main column of the Islamic thinking system the belief has always been in the center of attention in all historical periods. Particularly, regulation of all social, economic and public attitudes in the Islamic society, preparation of the sharia and figh laws has been in close connection with belief. Belief should be considered even in establishment of the social behavior norms. Thus, all components of the Islamic culture are not far from the norm and belief which regulate the individual and public life of the people. And it is the truth that if a man is healthy in belief, his behavior and actions will be right.

\section{References}

[1] Mehdiyev, R. A. 2010. Philosophy. Textbook. Translation from Second Edition in Russian. Baku, "East-West", 360.

[2] Philosophic and Encyclopedic Dictionary. 1997. Chairman of the Scientific Edition Council: I. Rustamov. Azerbaijani Encyclopedia. "Publication Polygraph Union”. Baku, 520.

[3] Farabi, A. N. T. 2006. Classification of Sciences. Publication House "Adiloghlu”, 212.

[4] Azerbaijani Philosophy History. 2014. Chief Editor: Real Member of the NACA, Academician F. G. Kocharli, in 2 volumes, I Vol.-Baku: "Elm”, 2014. 456. II Vol.-Baku: "Elm", 684.

[5] Ahmed, O. 1997. "Hanafi Figh Scientists." TDV Islam Encyclopedia, 16, Istanbul, 559.

[6] A-539 (manuscript). "Al-Fighul-Akbar" Abu Hanifa.

[7] Jalilov, E. 1995. Azerbaijani State and Law XII-XVI Centuries. State Book Chamber, Baku, 420.

[8] Sherafeddin, G., and Suleiman, T. 2001. History of Byword. Schools-Problems. Prof. Publ. Konya, 506.

[9] Suleiman, U. 1991. Science of Byword and Islamic Belief. Sherhul-akaid. Taftazani. Istanbul: Dargah Publications. $386+86$.

[10] Gazali, A. N. 1986. Kimyayi-saadat (Chemistry of Happiness). Translated from Persian by Nasib Goyushov. Vol. I. "East-West”, 646. 
[11] Chelebi, I. 2006. Mutezila. TDV Islam Encyclopedia, 31, Istanbul, 591.

[12] B-2397/4022 (anonymous) 41a-44b, Burhān at-Tovhīd.

[13] B-733/3282 collection (363b-372b) 1850. Aqā id an-Nasafi AhmadNacmuad-din abuCa far bin an-Nasafi bin Ismā il.

[14] C-807/9760. Burhān at-Tovhīd.

[15] Mammadov, Z. J. 1999. Eastern Philosophy (IX-XII Centuries). Baku: Publication of Baku University. 203. 